\title{
EFFECTS OF FEEDING EFFECTIVE MICROORGANISMS ON BLOOD LEVELS OF ANTIBODIES TO NEWCASTLE DISEASE VIRUS VACCINE AND TRACE ELEMENT IN BROILER CHICKS
}

\author{
DHYAA MOHAMMAD TAHER JWHER
}

Department of Veterinary Public Health, College of Veterinary Medicine, University of Mosul, Iraq E-mail: Deeam1973@yahoo.com

\section{ABSTRACT}

Received at: 26/2/2014

Accepted: 24/3/2014

\begin{abstract}
A total of 60 unsexed day old broiler chicks of (Ross 308) were divided into 2 groups, each of 30 chicks were housed in a separate individual pens, during the period $1^{\text {st }} / 10$ till $5^{\text {th }} / 112012$, for 5 weeks. Effective Microorganisms (EM) was administered at a rate of $10 \mathrm{ml} /$ liter of drinking water. Chicks were vaccinated against Newcastle disease (ND) (Lasota strain). Blood samples were collected and divided into two parts, one for estimation of trace elements (copper, zinc, cobalt and manganese) using Atomic absorption, while the other part for estimation of antibody titers against Newcastle disease virus. Results showed that there was a significant $(\mathrm{p}<0.05)$ increase in the antibody titers against Newcastle disease virus vaccine of $5347.07 \pm 117.03$, in chicks amended with EM when compared with the control group of $2949.24 \pm 314.51$. There was also a significant $(p<0.05)$ increase in the mean of trace elements of $\mathrm{Zn}, \mathrm{Co}, \mathrm{Cu}$ and $\mathrm{Mn}$ which are $(1.171 \mu \mathrm{g} / \mathrm{ml}$, $6.128 \mu \mathrm{g} / \mathrm{ml}, 0.376 \mu \mathrm{g} / \mathrm{ml}$ and $0.146 \mu \mathrm{g} / \mathrm{ml})$ in treated chicks with EM, in comparison with $(0.587 \mu \mathrm{g} / \mathrm{ml}, 4.151 \mu \mathrm{g} / \mathrm{ml}, 0.232 \mu \mathrm{g} / \mathrm{ml}$ and 0.000$)$ respectively in the control group.
\end{abstract}

Key word: Effective Microorganisms, Trace elements, Antibody titers

\section{INTRODUCTION}

Newcastle disease is a deadly viral contagious disease of poultry among chicken and other birds (Alexander and Senne, 2008). Newcastle disease is being controlled using prophylactic measures such as routine vaccination along with strict biosecurity measurements of many developed countries of the world (Liljebjelke et al., 2008). Different vaccination programs against ND are being practiced as a means of protecting birds from the frequent outbreak of the disease in broilers have been applied in Mosul Governorate Newcastle disease (ND) is being considered as one of the most important constrains for the development of profitable poultry farming including broiler both in the urban and rural area of Iraq.

A survey of maternal immunity of broiler chicks reared in Mosul broiler farms showed that they were influencing the optimum age of birds for ND vaccination (Mohammadamin and Qubih 2010), in addition to other factors of seasonal variation and prevalence of certain disease (Allan et al., 1978). As regard to the boosting effect of effective microorganisms on the immune system of birds when they are added to their diet or water, (Anjum et al., 1996) and (Jwher et al., 2013), reported greater bursa and thymus index which are the vital components of humoral and cellular immunity in birds supplemented with EM through drinking water and fermented feed. Effective microorganisms are formed at high pressures by the interaction of a diverse group of naturally occurring, aerobic and facultative anaerobic microorganisms. EM include high populations of lactic acid producing bacteria (Lactobacillus and Pedicoccus) at $1 \times 10^{5} \mathrm{CFU} / \mathrm{ml}$ suspension, yeast (Sacharomyces) at $2 \times 106 \mathrm{CFU} / \mathrm{ml}$ suspension and fewer amounts of photosynthetic bacteria, actinomyces and other organisms (Gum et al., 1998), Effective microorganisms are regarded in Japan to be effective as a probiotic, (Kitazato Environmental Science Center 1994). These flora could play an important role in the digestion process in intestinal tract of the birds, since their enzymes promote the digestion of protein, Iipids and carbohydrates and bacteria also synthesize vitamins that contribute to the nutrition of the bird (Larbier and Leclerco 1994). Many authors were referred to the beneficial effects of effective microorganisms in improving growth parameters: feed intake, weight gain, feed conversion ratio in broilers (Jwher et al., 2013; Safalaoh, 2006; Ergun et al., 2000; Silva et al., 2000; Kumprechtova et al., 2000; Chantsawang and Watcharangkul 1999; ZuAnon et al., 1998; Alvarez et al., 1994; Jagdish and Sen 1993). This paper was therefore conducted to study the effect of Effective Microorganisms on the 
Newcastle antibody titers and trace elements in blood of broiler chicks.

\section{MATERIALS and METHODS}

Management of Experimental Birds:

A total of 60 unsexed day old broiler chicks of (Ross 308) were divided into 2 groups each of 30 chicks were housed in a separate individual pens thoroughly cleaned and well prepared at the farm of the College of Veterinary Medicine/ Mosul University, during the period $1^{\text {st }} / 10$ till $5^{\text {th }} / 11$ 2012. Each group was randomly assigned to 2 replicates for a study period of 5 weeks (table 1). All the treatment groups were fed to appetite with commercial starters, grower and finisher rations and clean water were made available all the times (table 2).

Table 1: Treatment Allocation to the Experimental Chicks.

\begin{tabular}{cccc}
\hline Treatments & Rep/Treat. & Chicks/Rep. & Total \\
\hline 0 ml EM-1/Liter of drinking water, control & 2 & 15 & 30 \\
\hline $\mathbf{T 1}$ (10 $\mathbf{~ m l ~ E M - 1 / ~ L i t e r ~ o f ~ d r i n k i n g ~ w a t e r ~ ( T 2 ) ~}$ & 2 & 15 & 30 \\
\hline
\end{tabular}

Table 2: Feed composition (g/kg).

\begin{tabular}{|c|c|c|c|}
\hline Ingredients & Starter & Grower & Finisher \\
\hline Corn & 26.8 & 54.3 & 50.6 \\
\hline Wheat & 20.0 & 17.4 & 27.0 \\
\hline Barley & 20.0 & - & - \\
\hline Soybean Meal (48\%) & 27.0 & 23.0 & 17.0 \\
\hline Fat & 1.7 & 1.0 & 1.0 \\
\hline Ground Limestone & 1.6 & 1.5 & 1.5 \\
\hline Calcium Phosphate (20\% P) & 1.5 & 1.5 & 1.5 \\
\hline Iodized Salt & 0.3 & 0.22 & 0.3 \\
\hline Vitamin: mineral $^{1}$ premix & 1.0 & 1.0 & 1.0 \\
\hline Methionine & 0.10 & 0.08 & 0.10 \\
\hline \multicolumn{4}{|c|}{ Calculated analysis } \\
\hline Crude Protein & 22.0 & 18.0 & 16.1 \\
\hline Digestible protein $(\%)$ & 17.7 & 14.4 & 12.9 \\
\hline Crude Fat $(\%)$ & 5.9 & 3.4 & 3.4 \\
\hline Metabolized Energy (kcal/kg) & 3060 & 3022 & 3050 \\
\hline Calcium $(\%)$ & 1.00 & 0.95 & 0.96 \\
\hline Av. Phosphorus (\%) & 0.42 & 0.41 & 0.41 \\
\hline Sodium $(\%)$ & 0.17 & 0.17 & 0.18 \\
\hline Methionine (\%) & 0.48 & 0.38 & 0.37 \\
\hline Methionine \&Cysteine (\%) & 0.82 & 0.65 & 0.61 \\
\hline Tryptophan $(\%)$ & 0.31 & 0.25 & 0.22 \\
\hline Lysine (\%) & 1.25 & 0.93 & 0.78 \\
\hline Threonine $(\%)$ & 0.94 & 0.75 & 0.65 \\
\hline
\end{tabular}

*(Leeson and Summers 1997)

Liquid form of EM product (Alannam company for natural agriculture, Tortuous-Syria under the supervision of EMRO Japanese institute - OkinawaJapan) was used. EM stock solution is formed from Lactic acid bacilli: Lactobacillus plantarum; L. casei Streptococcus Lactis.; Photosynthetic bacteria Rhodopseudomonas palustris; Rhodobacter sphaeroides, Yeast; Saccharomyces cerevisiae;
Candida utilis torula, Pichia jadinii; Actinomycetes; Streptomyces albus; S. griseus and Fermenting fungi; Aspergillus oryzae; Mucor hiemalis.as described by the manufacturer. EM was administered at a rate of $10 \mathrm{ml} /$ liter of drinking water as shown in T2. Standard bio-security protocol was employed throughout the experimental period. Chicks were 
vaccinated against Newcastle disease (Lasota strain) at 8 and 18 days of age.

\section{Blood collection}

Blood samples were collected from each bird at the end of the experiment (35) days by wing vein puncture and then were divided into two parts, one part in test tubes with EDTA for estimation of trace elements (copper, zinc, cobalt and manganese) using Atomic absorption (GBC Scientific equipment PTY LTD Australia). The other part was allowed to clot in plastic tubes at room temperature (Alexander, 1988) for three hours. After that the clot was loosened and the tubes were stored at $4 \mathrm{C}^{0}$ overnight. Serum was removed in the second day and stored in $-20^{\circ} \mathrm{C}$. The serum was then tested for antibody titers against Newcastle disease virus.

\section{ELISA:}

Sixteen sera samples were used for analyzing ND antibody titers using ELISA kits as prescribed by the manufacture (Symbiotic, Co., San Diego, USA).

\section{Trace elements:}

Trace elements (copper, zinc, cobalt and manganese) were estimated using Atomic absorption (GBC Scientific equipment PTY LTD Australia) with the methods represented in table 3.

Table 3: Instrument parameters for trace elements estimation in blood samples of broiler chicks.

\begin{tabular}{|c|c|c|c|c|}
\hline \multicolumn{5}{|c|}{ Instrument parameters } \\
\hline Elements & $\mathrm{Zn}$ & $\mathrm{Cu}$ & $\mathrm{Co}$ & $\mathrm{Mn}$ \\
\hline System type & Flame & Flame & Flame & Flame \\
\hline Lamp current & 5.0 Am & $3.0 \mathrm{~mA}$ & $6.0 \mathrm{~mA}$ & $5.0 \mathrm{Am}$ \\
\hline Wavelength & $213.9 \mathrm{~nm}$ & $324.7 \mathrm{~nm}$ & $240.7 \mathrm{~nm}$ & $279.8 \mathrm{~nm}$ \\
\hline Slit width & $0.5 \mathrm{~nm}$ & $0.5 \mathrm{~nm}$ & $0.2 \mathrm{~nm}$ & $0.2 \mathrm{~nm}$ \\
\hline Measurement mode & Integration & Integration & Integration & Integration \\
\hline Sample introduction & Manual & Manual & Manual & Manual \\
\hline Read time & 3.0 & 3.0 & 3.0 & 3.0 \\
\hline Calibration mode & $\begin{array}{l}\text { Linear LS } \\
\text { through Zero }\end{array}$ & $\begin{array}{c}\text { Linear LS through } \\
\text { Zero }\end{array}$ & $\begin{array}{c}\text { Linear LS through } \\
\text { Zero }\end{array}$ & $\begin{array}{c}\text { Linear LS } \\
\text { through Zero }\end{array}$ \\
\hline Conc. unit & $\mu \mathrm{g} / \mathrm{ml}$ & $\mu \mathrm{g} / \mathrm{ml}$ & $\mu \mathrm{g} / \mathrm{ml}$ & $\mu \mathrm{g} / \mathrm{ml}$ \\
\hline Conc. Decimal places & 5 & 5 & 3 & 5 \\
\hline $\begin{array}{l}\text { Check sample lower } \\
\text { range }\end{array}$ & $1.000 \mu \mathrm{g} / \mathrm{ml}$ & $1.000 \mu \mathrm{g} / \mathrm{ml}$ & $1.000 \mu \mathrm{g} / \mathrm{ml}$ & $1.000 \mu \mathrm{g} / \mathrm{ml}$ \\
\hline Flame type & Air- Acetylene & Air- Acetylene & Air- Acetylene & Air- Acetylene \\
\hline Fuel flow & $2.00 \mathrm{l} / \mathrm{m}$ & $2.00 \mathrm{l} / \mathrm{m}$ & $2.00 \mathrm{l} / \mathrm{m}$ & $2.00 \mathrm{l} / \mathrm{m}$ \\
\hline Oxidant flow & $10.0 \mathrm{l} / \mathrm{m}$ & $10.0 \mathrm{l} / \mathrm{m}$ & $10.0 \mathrm{l} / \mathrm{m}$ & $10.0 \mathrm{l} / \mathrm{m}$ \\
\hline
\end{tabular}

\section{Statistical Analysis:}

Data were presented as means \pm S.E. and were analyzed using two way analysis of variance (ANOVA) using significant level of $(\mathrm{P}<0.05)$. Specific group differences were determined using Duncan's multiple range test as described by (Duncan, 1995). 


\section{RESULTS}

\section{ELISA antibody titers:}

Addition of $10 \mathrm{ml}$ of effective microorganisms / d drinking water has a significant $(\mathrm{p}<0.05)$ positive effect on the antibody titers against Newcastle disease virus vaccine of 5336.09 \pm 122.08 , in comparison with the control group of $2921.51 \pm 275.40$ (Fig.1).

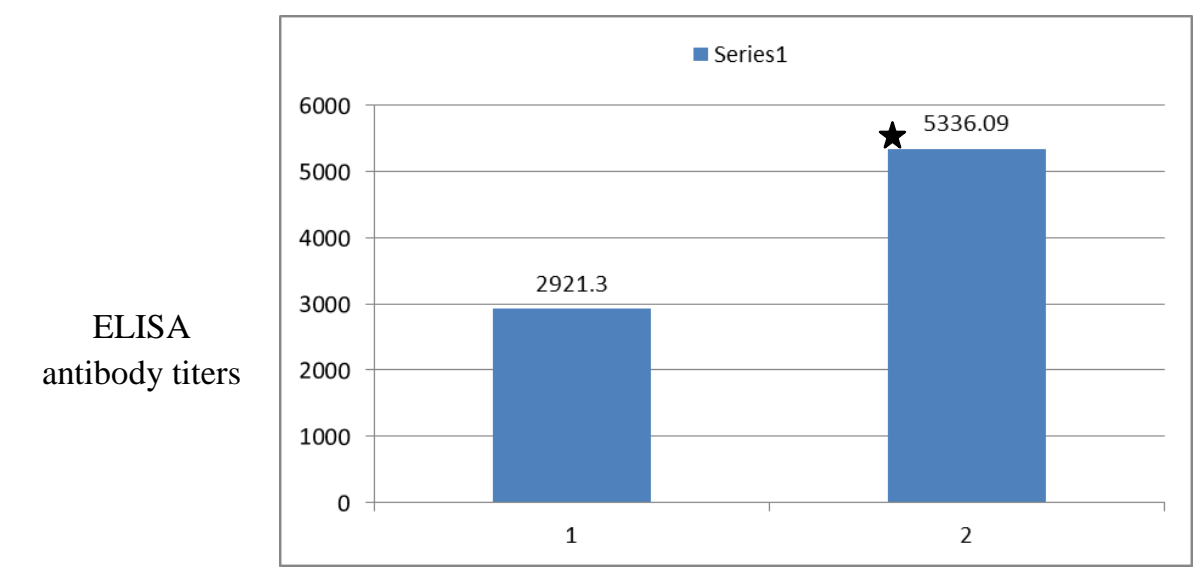

significant at $(\mathrm{p}<0.05)$

Figure 1: Effect of Effective microorganisms on the ELISA antibody titers against Newcastle disease virus vaccine in broiler chicks.

\section{Trace elements:}

Addition of $10 \mathrm{ml}$ of effective microorganisms $/ 1$ drinking water has a significant $(\mathrm{p}<0.05)$ positive effect on the mean trace elements of $\mathrm{Zn}, \mathrm{Co}, \mathrm{Cu}$ and $\mathrm{Mn}$ of $(1.171 \mu \mathrm{g} / \mathrm{ml}, 6.128 \mu \mathrm{g} / \mathrm{ml}, 0.376 \mu \mathrm{g} / \mathrm{ml}$ and $0.146 \mu \mathrm{g} / \mathrm{ml})$ in comparison with $(0.587 \mu \mathrm{g} / \mathrm{ml}, 4.151 \mu \mathrm{g} / \mathrm{ml}, 0.232 \mu \mathrm{g} / \mathrm{ml}$ and 0.000$)$ respectively in the control group (Table 4).

Table 4: Effect of Effective microorganisms on the blood concentrations of trace elements in broiler chicks.

\begin{tabular}{ccccc}
\hline \multirow{2}{*}{ Elements } & \multicolumn{2}{c}{ Mean $\boldsymbol{\mu g} / \mathbf{m l}$} & \multicolumn{2}{c}{ Range $\boldsymbol{\mu g} / \mathbf{m l}$} \\
\cline { 2 - 5 } & $\mathbf{T 1}$ & $\mathbf{T 2}$ & $\mathbf{T 1}$ & $\mathbf{T 2}$ \\
\hline Zn & $0.587 \pm 0.0789$ & $1.171 \pm 0.0831^{*}$ & $0.130-0.820$ & $0.820-1.620$ \\
\hline Co & $4.151 \pm 0.507$ & $6.128 \pm 0.549^{*}$ & $1.190-5.530$ & $5.140-7.230$ \\
\hline Cu & $0.232 \pm 0.0204$ & $0.376 \pm 0.0134^{*}$ & $0.281-0.312$ & $0.754-1.434$ \\
\hline Mn & $0.124 \pm 0.0428$ & $0.284 \pm 0.134^{*}$ & $0.0598-0.550$ & $0.128-1,620$ \\
\hline
\end{tabular}

*significant at $(\mathrm{p}<0.05)$

\section{DISCUSSION}

Effective micro-organisms were administered to broiler chicks in the form of "EM solution" to study its effect on immune response and some of the blood trace elements of broiler chicks. Our results relating to Antibody titers against (ND) virus vaccine confirmed the previous work of (Monoura et al., 2008). (Anjum et al., 1996) who also reported that Antibody geometric mean titre (GMT) against Newcastle disease vaccine virus was 6.5 times in broilers given EM in drinking water, 3.85 times in broilers given EM fermented feed and 3.73 times in broilers given both EM in drinking water and fermented feed. Our results were also in the line of (Monoura et al., 2008) on the ELISA antibody titre which was also higher in treated broilers with EM (4675.12 \pm 485.72$)$ compared to $(2169.38 \pm 724.45)$ in control group.

EM was reported to support immune system through significant increase in the relative weights of immune system organs (Bursa, thymus and spleen) (Liljebjelke et al., 2008; Safalaoh, 2006; Anjum et al., 1996). (Shoeib et al., 1997), reported that the bursa of probiotic treated chickens showed an 
increase in the number of follicles with high plasma cell reaction in the medulla. Since the mid-1980's, livestock researchers and producers in Japan began to test EM to be effective as a probiotic, (Kitazato Environmental Science Center 1994), and probiotics were reported in broiler chicks to have positive effects on immune organs (Willis et al., 2007), by increase lymphocyte (Abdollahi et al., 2003), on the increase of the phagocytic activity of leukocytes and the phagocytic index in broilers (Shareef and AlDabbagh 2009). The positive effect of feeding diet containing probiotics on the immune response could be due to their direct effect which may be related to stimulate the lymphatic tissue (Kabir et al., 2004), or indirect via changing the normal microbial population flora of the lumen of gastrointestinal tract. Additionally, (Christensen et al., 2002) suggested that some of these effects were mediated by cytokines secreted by immune system cells stimulated with probiotic bacteria. Notably, It has been concluded that EM is immune modulator in broilers since treated birds had significantly more serum antibodies than those served as control birds (Haghighi et al., 2005; Ahmed et al., 1996).

The higher levels of all trace elements tested were shown in blood of broiler group amended with $10 \mathrm{ml}$ of EM in the drinking water compared to those of the control. These findings may be related to the inoculation of the gastro-intestinal tract with beneficial microorganisms. The gastro-intestinal tract of birds is host to approximately 40 species of microorganisms with 3 or more different types of each one. The flora plays an important role in the digestion process. Bacterial enzymes promote the digestion of protein, lipids and carbohydrates and bacteria also synthesize vitamins that contribute to the nutrition of the bird (Larbier and Leclerco 1994). According to (Yongzhen and Waijiong 1994) EM Probiotic improves the coefficient of nitrogen absorption in the animal. After 45 days of EM treatment in day-old commercial broilers; live body weight was approximately 2004 grams for broilers given EM in drinking water, approximately 1978 grams for broilers given EM fermented feed and approximately 2022 grams for broilers given EM in both ways, compared to approximately $1690 \mathrm{~g}$ of the control broilers. (Yongzhen and Waijiong 1994) also found that the concentration of amino acids in the feed was improved $28 \%$ after the fermentation process with EM, indicating that EM improves the quality of the feed. A study that took place in the Aichi Prefecture in Japan with 70,000- 80,000 Arbor Acre broilers using EM for two years, showed an improvement in the feed conversion rate and an increase in the weight increase per day. The average broiler weight at shipment went from $2.68 \mathrm{Kg}$ to 2.9 $\mathrm{Kg}$. EM was given in the drinking water once a week and it was also sprayed inside and outside the chicken house before the birds were brought in (Kitazato
Environmental Science Center 1994). In the same line were the results of (Jwher et al., 2013), who found a significant improvement in body weight gain of broilers amended with EM in their drinking water $(2019.8 \pm 63.7 \mathrm{~g}$ of treated group vs. $1758 \pm 34.52$ in control group at 35 days of age. Moreover the intestinal mucosal architecture can reveal useful information on the intestinal function. The histological changes found in small intestines of the treated group probably had increased the intestinal surface area, facilitating the nutrient absorption to a greater extent and, thus boosted the promoting growth effect of certain probiotic (EM) supplementation. (Samanya, and Yamauchi 2002) found that longer villi in the ileum of adult male birds with slight improvement in feed efficiency after dietary addition of Bacillus subtilis var. natto and in broilers after addition Enteroccocus faecium. In addition to that, the increase releasing of mucin by goblet cells inhibit the reproduction of harmful bacteria in the intestine (Rahimi et al., 2009) Increasing the villus height suggests an increased surface area capable of greater absorption of available nutrients. The intestinal mucosal architecture and its relation to nutrient absorption and performance enhancement was found by (Jwher et al., 2013). The trace minerals which are of primary concern in poultry diets having recommended levels of supplementation in the ration formulated and given in this study which is in the same time as recommended by the (NRC 1984) Nutrient Requirements of Poultry include Zinc (Zn), Manganese $(\mathrm{Mn})$, Copper $(\mathrm{Cu})$, Iron $(\mathrm{Fe})$, Selenium (Se) and Iodine (Leeson, 2005). The higher levels of $\mathrm{Zn}, \mathrm{Co}, \mathrm{Cu}$ and $\mathrm{Mn}$ in treated broilers with $10 \mathrm{ml}$ of EM in their drinking water than those of control have a profound beneficial effect on the antibody titers against (ND) virus vaccine reported here, since $\mathrm{Zn}$, $\mathrm{Co}, \mathrm{CU}$ and $\mathrm{Mn}$ play a crucial role in human and animal immunity (Arthington and Havenga 2011; Sajadifar et al., 2011; Larry and Berger 2006; Chaturvedi et al., 2004; Patidar et al.,1999). Zinc as an example and its metalloenzymes in the poultry including carboxypeptidases and DNA polymerases enzymes, play important roles in the birds immune response, and their deficiency in poultry could include a suppressed immune system, both humoral and cellular responses (Sajadifar et al., 2011; Sheila, 2008). In conclusion, and under the conditions of this experiment it is found that $\mathrm{EM}$ has a significant positive effect on the immunity of broiler chicks against vaccination to ND vaccine and to improve the trace element status of broiler chicks.

\section{REFERENCES}

Abdollahi, M.R.; Kamyab, A.; Bazzazzadekan, A.; Nik-khah, A. and Shahneh, A.Z. (2003): Effect of different levels of bacterial probiotic on broilers performance. Proceedings of the British Society of Animal Science. No.185. 
Ahmed, D.A.; Hussain, T.; Rivizi, F.; Gilani, G. and Javid, T. (1996): Influence of EM on health and immune system of broilers under experimental condition. University of Agriculture, Faisalabad- 38040. Pakistan http://www.emturkey.com.tr/TR/dosya/1 368/h/broiler-immune-health. pdf.

Alexander, D.J. and Senne, D.A. (2008): Newcastle Disease, Other Avian Paramyxoviruses, and Pneumovirus Infections. In: Diseases of Poultry, Twelfth Edition, Saif Y.M., Fadly A.M., Glisson J.R., McDougald L.R., Nolan L.K. \& Swayne D.E., eds. Iowa State University Press, Ames, Iowa, USA, 75-116.

Alexander, D.J. (1988): Newcastle diagnosis, in Newcastle disease. London, U.K. Kluwer Academic: 147-159.

Allan, W.H.; Lancaster, J.E. and Toth, B. (1978): Newcastle disease vaccines, their production and use. Animal Production Series. Chapter 3. Selection of the vaccine seed strain, pp. 10-18. Food and Agricultural Organization of the United Nations, Rome.

Alvarez, L.C.; Barrera, E.M. and Gonzalez, E.A. (1994): Evaluation of growth promoters for broiler chickens. Veterinaria Mexico, 25: 141-144.

Anjum, A.; Hussain, T.; Rizvi, F.; Gilani, G. and Javaid, T. (1996): Influence of Effective Microorganisms on Health and Immune System of Broilers Under Experimental Conditions.5th Conf. on the Technology of Effective Microorganisms at Sara Buri, Thailand on 10-11Dec. Organized by APNAN and INFRC. P-5.

Arthington, J.D. and Havenga, L.J. (2011): Effect of injectable trace minerals on the humoral immune response to multivalent vaccine administration in beef calves. J. Anim Sci. 2012 Jun; 90(6): 1966-71. doi: 10.2527/jas.2011-4024. Epub, Dec 16.

Chaturvedi, Richa Shrivastava, U.C. and Upreti, R.K. (2004): Viral infections and trace elements: A complex interaction1536 current science, vol. 87, No. 11.

Chantsawang, S. and Watcharangkul, P. (1999): Influence of effective microorganisms on the quality of poultry products. In: Proceedings of International Conference on Kyusei Nature Farming, October 23-26, 1997, Sara Buri, Thailand, pp: 133-150.

Christensen, H.R.; Frokiaer, H. and Pestka, J.J. (2002): Lactobacilli differentially modulate expression of cytokines and maturation surface markers in murine dendritic cells. Journal of immunology. 186: 171-178.

Duncan, D.B. (1995): "Multiple range and multiple F test," Biometrics. 1:11-42.

Ergun, A.; Yalcin, S. and Sacakli, P. (2000): The usage of probiotic and zinc bacitracin in broiler rations. Ankara Universities Veteriner Facultesi Dergisi, 47:271-280.

Gum, A.; Andrade, P.; Iturrino-Schocken, R.P. and Malheiros, E.B. (1998): Aerobic Stability of Wilted Grass Silages (Pennisetum purpureum, Schum) Treated with Microbial Inoculant. Fundacao Moki'ti Okada and Universidade Estadual Paulista, Jaboticabal Campus, Sao Paulo, Brazil.

Haghighi, H.R.; Gong, J.; Gyles, C.L.; Hayes, M.A.; Sanei, B.; Parvizi, P.; Gisavi, H.; Chambers, J.R. and Sharif, S. (2005): Modulation of antibody-mediated immune response by probiotics in chickens. Clin Diagn Lab Immunol. 12: 1387-1392.

Jagdish, P. and Sen, A.K. (1993): Effect of different growth promoters on the performance of broilers. Poult. Advisory, 26: 49-51.

Jwher, Dh. M.T.; Abd, S.K. and Mohammad, A.G. (2013): The study of using Effective Microorganisms (EM) on health and performance of broiler chicks. Iraqi J. of Vet. Sci. Vol. 27:No. 2.

Kabir, S.M.L.; Rahman, M.M.; Rahman, M.B. and Ahmed, S.U. (2004): The dynamics of probiotics on growth performance and immune response in broilers. International Journal of Poultry Science. 3: 361-365.

Kitazato Environmental Science Center. (1994): What is EM? EM is Non Toxic, lp. Application of EM in Livestock Farming, 2p. Case Study 1 (Effects of EM in Broiler Production: The reduction of costs and disinfectants), 3p. Case Study 2 (Effects of EM in laying hen raising: Foul odor reduction and egg quality improvement), 4p. Case Study 3 (Effects of EM on raising laying hens: Foul odor reduction and health improvement), 3p. Case Study 4 (Improvement of milk quality by using EM; Experiments 1 and 2), 4p.

Kumprechtova, D.; Zobac, P. and Kumprecht, I. (2000): The effect of Sacchromyces cervisiae SC47 on chicken broiler performance and nitrogen output. Czech J. Anim. Sci., 45: 169-177.

Larbier, M. and Leclerco, B. (1994): Nutrition and Feeding of Poultry. Nottingham University Press. U.K. 305 p.

Larry, L. and Berger, T.J.C. (2006): Salt and Trace Minerals for Livestock, Poultry and Other Animals Published by the Salt Institute 700 North Fairfax Street, Suite 600 Alexandria, Virginia 22314-2040.

Leeson, S. (2005): Trace mineral requirements of poultry-validity of the NRC recommendations. Published in "Re-defining Mineral Nutrition" edited by JA Taylor-Pickard and LA Tucker, Nottingham University Press, Nottingham, United Kingdom. 
Leeson, S. and Summers, J.D. (1997): Commercial poultry nutrition. $2^{\text {nd }}$ Edition. University books, Guelph, Ontario. 210-211.

Liljebjelke, K.A.; King, D.J. and Kapczynski, D.R. (2008): Determination of Minimum Hemagglutinin Units in an Inactivated Newcastle Disease Virus Vaccine for Clinical Protection of Chickens from Exotic Newcastle Disease Virus Challenge. Avian Diseases 52(2): 260-268.

Mohammadamin, O.G. and Qubih, T.S. (2010): Effect of industrial product $\mathrm{IMBO}^{\circledR}$ on immunosuppressed broilers Vaccinated with Newcastle disease vaccine. Iraqi Journal of Veterinary Sciences, Vol. 24, No.1: 37-40.

Monoura, P.; Rahman, M.; Khan, M.F.R.; Rahman, M.B. and Rahman, M.M. (2008): Effect of vitamins, minerals and probiotics on production of antibody and live weight gain following vaccination with bcrdv in broiler birds Bangl. J. Vet. Med. 6 (1): 31-36.

NRC. (1984): Nutrient Requirements of Poultry. 8th revised ed. National Academy Press. Washington, D.C.

Patidar, S.K. and Prajapati, J.B. (1999): Effect of feeding Lactobacilli on serum antibody titer and faecal microflora in chicks. Microbiologic Aliments Nutr., 17: 145-154.

Rahimi, S.; Grimes, J.I.; Fletcher, O.; Oviedo, E. and Sheldon, B.W. (2009): Effect of direct fed microbial primalac on structure and ultrastructure of small intestine in turkey poults. Poult Sci. (88); 491-503.

Safalaoh, A.C.L. (2006): Body weight gain, dressing percentage, abdominal fat and serum cholesterol of broilers supplemented with a microbial preparation. Afr. On Line J. Food, Agric. Nutr. Dev., 6: 1-10.

Samanya, and Yamauchi. (2002): Histological alterations of intestinal villi in chickens fed dried Bacillus subtilis var. Natto. Comp Bioch Physio. 133: 95-104.
Sajadifar, S.; Miranzadeh, H. and Moazeni, M. (2011): Immune Responses of broiler chicks supplemented with high levels of zinc. Scienceline Publication. Online Journal of Animal and Feed Research.

Shareef, A.M. and Al-Dabbagh, A.S.A. (2009): Effect of probiotic (Saccharomyces cerevisiae) on performance of broiler chicks. Iraqi J. Vet. Sci. 23: 23-29.

Sheila, E. (2008): Trace mineral balance in poultry. Dept. of Animal Science, University of Nebraska, Lincoln, NE, U.S.A. Worlds poultry journal, avilable at http://www. zootecnicainternational.com/comp- onent/ content/article/5-nutrition/284-trace-mineralbalance-in-poultry. Html.

Shoeib, H.K.; Sayed, A.N.; Sotohy, S.A. and Abdel Ghaffar, S.K. (1997): Response of broiler chicks to probiotic (pronifer) supplementation. Assiut Veterinary Medical Journal. 36: 103-116.

Silva, E.N.; Teixeira, A.S.; Bertechini, A.G.; Ferreira, C.L. and Ventura, B.G. (2000): Ciencia e Agrotecnologia. 24: Ed. Especial, 224-232. Vicente JL, Aviña L, Torres-Rodriguez A, Hargis B. and Tellez G. 2007. Effect of a Lactobacillus sp.- based probiotic culture product on broiler chicks performance under commercial conditions. Int. J. Poult. Sci., 6: 154-156.

Willis, W.L.; Isikhuemhen, O.S. and Ibrahim, S.A. (2007): Performance assessment of broiler chickens given mushroom extract alone or in combination with probiotics. Poultry Science. 86:1856-60.

Yongzhen, N. and Waijiong, L. (1994): Report on the Debdorizing Effect of Effective Microorganisms (EM) in Poultry Production. Beijing, China. 4p.

ZuAnon, J.A.; Fonseca, S.; Rostagno, H.S.; Almeida, M. and Silva, M. (1998): Effects of growth promoters on broiler chicken performance. Revista Brasileira de Zootecnia, 27: 999-1005.

\title{
تاثير اضافة الاحياء المجهرية الفعالة (EM) على مستوى الاجسام المضادة لفيروس مرض النيوكاسل ومستوى المعادن في افراخ فورج الاجمام المطن
}

\author{
ضباء محمد طاهر جوهر \\ E-mail: Deeam1973@yahoo.com
}

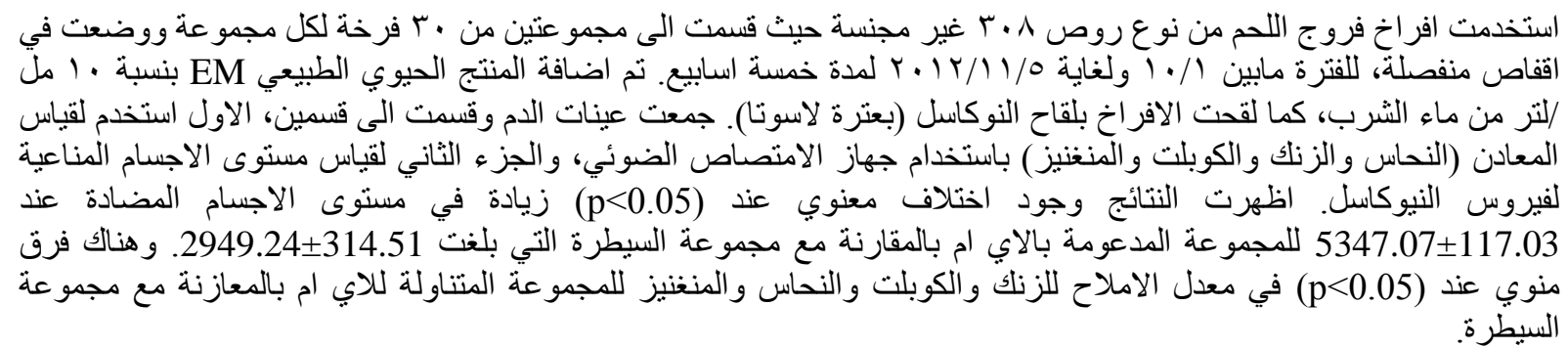

